\title{
PEMANFAATAN FUNGI MIKORIZA ARBUSKULA DAN POT ORGANIK UNTUK MENINGKATKAN PERTUMBUHAN SUREN (Toona sinensis Roem.) DI PERSEMAIAN PERMANEN IPB DRAMAGA
}

\author{
The utilization of arbuscular mycorrhizal fungi and organic pot to enhance Suren (Toona sinensis \\ Roem.) growth at IPB Dramaga Permanent Nursery
}

Sri Wilarso Budi ${ }^{1^{*}}$ dan Dwi Puspasari Arum Ramadhani ${ }^{2}$

(Diterima Desember 2019/Disetujui Agustus 2020)

\begin{abstract}
The cultivation of seedling which uses polybag caused the increase of polybag demand. Due to the rising demand of polybag, the rate of pollution caused by polybag waste is increasing as well, so that it requires an alternative to solve the problem by using organic based pot which is environmentally friendly and easily degraded. This study aimed to analyze the effect of Arbuscular Mycorrhizal Fungi (AMF) adding and the utilization of organic based pot to the growth of Suren (T. sinensis) seedling. This study was conducted using completely randomized design with two factor method, as well as observation for 16 weeks. The results showed that the interaction of organic pot composition treatment and AMF addition were significantly affected to the both parameters of height and diameter, while the treatment of organic pot composition was significantly affected to the parameter of total dry weight, moreover the treatment of AMF addition was significantly affected to the parameter of colonization of AMF. The results of this study indicated that the treatment of newspaper: rice husk gave better response of growth than other treatments.
\end{abstract}

Keywords: Arbuscular Mycorrhizal Fungi, suren (T. sinensis), organic pot

\section{PENDAHULUAN}

Hutan merupakan sumber daya alam yang memiliki peranan yang besar dalam berbagai aspek kehidupan seperti aspek ekonomi, aspek sosial dan aspek ekologi dengan keanekaragaman flora dan fauna yang memberikan manfaat bagi kehidupan manusia. Indonesia memiliki kawasan hutan mencapai 99,6 juta hektar atau $52,3 \%$ dari semua luas wilayah daratan Indonesia ( Kementerian Kehutanan 2011). Namun kontribusi subsektor kehutanan berupa kayu bulat terhadap pendapatan domestik bruto (PDB) relatif kecil yaitu sebesar 1,0 \% dan menjadi 2,0\% apabila digabung dengan nilai tambah industri pengolahan kayu (Astana 2012). Menurut Kementerian Kehutanan (2011) masalah kehutanan yang mengancam Indonesia adalah degradasi dan deforestasi hutan yang berdasarkan hasil penafsiran citra landsat pada periode 2003-2006 laju deforestasi di Indonesia sebesar 1,2 juta ha / tahun. Suatu upaya untuk memulihkan laju degradasi dan laju deforestasi hutan dapat dilakukan kegiatan pembangunan Hutan Tanaman Industri (HTI), Hutan Tanaman Rakyat (HTR),rehabilitasi dan reklamasi hutan (Sjarief 2010).

Program penanaman yang dapat mengoptimalkan keberhasilan dari upaya-upaya tersebut memerlukan ketersediaan bibit dalam jumlah yang cukup banyak. Penanaman bibit tanaman kehutanan pada umumnya

\footnotetext{
${ }^{1}$ Staf Pengajar Departemen Silvikultur, Fakultas Kehutanan dan Lingkungan Institut Pertanian Bogor

* Penulis korespondensi: e-mail: wilarso62@yahoo.com

${ }^{2}$ Mahasiswa Departemen Silvikultur, Fakultas Kehutanan Institut Pertanian Bogor
}

masih menggunakan polybag sebagai wadah media tumbuhnya. Apabila jumlah bibit tanaman yang diperlukan banyak maka kebutuhan polybag juga akan semakin meningkat. Penggunaan polybag dipilih karena memiliki keuntungan yaitu biaya lebih murah, perawatan mudah, menghemat ruang dan komposisi media tanam dapat diatur. Namun kerugian dari polybag tersebut yaitu daya tahan terbatas, kekurangan unsur hara, sekali pakai dan akan menjadi limbah yang sulit di uraikan (Syahputra 2011). Apabila suatu kebutuhan polybag semakin meningkat maka tingkat pencemaran akibat limbah polybag tersebut juga akan semakin meningkat. Solusi untuk mengatasi masalah tersebut yaitu dengan menggunakan wadah semai berbahan dasar organik yang dapat terurai dan ramah lingkungan.

Penilitian wadah semai berbahan dasar organik sebelumnya telah dilakukan oleh Syaputra (2011), Budi et al. (2012), Hafsyah (2015) dan Rohmah (2015), dimana komposisi wadah semai yang digunakan oleh masing-masing peneliti memberikan hasil terbaik pada pertumbuhan G. arborea, T. sinensis, dan M. azedarach. Namun penelitian tersebut tidak menggunakan perlakuan dengan FMA, dalam bidang kehutanan FMA dapat memberikan keuntungan terhadap tanaman inangnya seperti penyerapan unsur hara, air dan pencegahan masuknya patogen akar (Kartika 2006). Oleh karena itu perlu dilakukan penelitian terhadap penambahan FMA dan penggunaan wadah semai organik terhadap pertumbuhan bibit tanaman yang akan di teliti. Jenis bibit tanaman yang digunakan untuk bahan penelitian yaitu suren dengan komposisi pot organik terdiri atas koran, cocopeat, dan arang sekam. 
Tujuan penelitian ini yaitu untuk menganalisis pengaruh penambahan Fungi Mikorhiza Arbuskula dan penggunaan pot dari bahan organik terhadap pertumbuhan semai suren ( $T$. sinensis).

\section{METODE PENELITIAN}

\section{Waktu dan Lokasi Penelitian}

Penelitian dilaksanakan pada bulan Mei 2015 - April 2016. Lokasi penelitian dilaksanakan di Persemaian Permanen Dramaga IPB. Penghitungan kolonisasi FMA dilakukan di Laboratorium Teknologi Mikoriza dan Kualitas Bibit Departemen Silvikultur Fakultas Kehutanan IPB. Analisis tanah dilakukan di Laboratorium Analisis Tanah Departemen Manajemen Sumberdaya Lahan Fakultas Pertanian IPB.

\section{Alat dan Bahan}

Alat-alat yang digunakan dalam penelitian ini adalah alat pencetak pot, ayakan tanah, saringan, kompor, wajan, ember, drum berukuran besar, alat penyiram, gunting, caliper, curter, alat tulis, kalkulator, plastik kecil, label, potray, kamera, neraca analitik, penggaris, dan seperangkat komputer.

Bahan-bahan yang digunakan dalam penelitian ini adalah semai suren, koran bekas, tanah topsoil, cocopeat, dan arang sekam.

\section{Prosedur Penelitian}

Tahapan dari penelitian ini yaitu:

\section{Persiapan Pot Organik}

Kertas koran dihancurkan dan direndam kedalam drum berisi air kurang lebih selama 2 minggu dan dilakukan pengadukan. Apabila kertas koran sudah menjadi bubur dilakukan penyaringan untung mengurangi kadar air. Pencampuran bubur kertas koran dengan bahan pencampur lain memiliki perbandingan: bubur kertas koran 100\% (kontrol), bubur kertas koran + cocopeat (1:3), bubur kertas koran + arang sekam (2:3), bubur kertas koran + cocopeat + arang sekam $(1: 1: 1)$.

Pencetakan pot organik menggunakan alat khusus untuk mencetak pot sehingga akan berbentuk kerucut. Selanjtnya dilakukan pengeringan selama 4 hari atau di oven pada suhu $80^{\circ} \mathrm{C}$.

\section{Perkecambahan Suren}

Benih suren dikecambahkan pada bedengan dengan media campuran topsoil dan arang sekam.

\section{Pemilihan Semai Suren}

Semai yang dipilih yaitu semai suren yang memiliki umur 2 minggu dengan tinggi $4-5 \mathrm{~cm}$.

\section{Persiapan Media Sapih}

Media yang digunakan yaitu topsoil yang disangrai terlebih dahulu agar steril. Proses sangrai kurang lebih dilakukan selama 1 jam.

\section{Penyapihan Semai}

Penyapihan dilakukan pada sore hari untuk mengurangi penguapan.

\section{Inokulasi Tanaman}

Inokulum FMA berupa zeolith yang berisi mikoriza jenis Gigaspora sp. diperlukan untuk setiap pot organik dengan dosis 18 gram ( \pm setara dengan 50 spora). Inokulasi pada tanaman dilakukan pada saat penyapihan dengan meletakkan inokulum FMA pada lubang tanam.

\section{Pemeliharaan}

Pemeliharaan semai yang sudah disapih dilakukan dengan penyiraman 2 kali sehari pada pagi dan sore hari, serta dilakukan pembersihan gulma.

\section{Pengamatan dan Pengambilan Data}

Pengamatan semai suren dilakukan selama 16 minggu dengan parameter yang diamati yaitu tinggi dan diameter semai. Setelah dilakukan pengamatan, tahap selanjutnya dilakukan pemanenan dengan menghancurkan pot organik dan memisahkan tanaman dengan media.

Parameter yang diukur setelah pemanenan yaitu kandungan unsur hara pot organik dan media tanam (N,P total, P tersedia, C), berat kering total, Nisbah Pucuk Akar (NPA), dan kolonisasi mikoriza.

\section{Rancangan Percobaan dan Analisis Data}

Percobaan penelitian yang dilakukan dengan menggunakan Rancangan Acak Lengkap (RAL) dengan dua faktor, dimana faktor A adalah komposisi pot dan faktor B adalah penambahan mikorhiza. Faktor A terdiri dari 4 perlakuan yaitu A1 : bubur kertas koran $100 \%$, A2: bubur kertas koran + cocopeat $(1: 3)$, A3: bubur kertas koran + arang sekam (2:3), A4: bubur kertas koran + cocopeat + arang sekam $(1: 1: 1)$. Faktor B terdiri dari 2 perlakuan yaitu B1: tanpa FMA dan B2: dengan FMA. Setiap perlakuan pada faktor A dikombinasikan dengan perlakuan dari faktor B menjadi $\mathrm{AB}$, sehingga terdapat 8 kombinasi. 1 kombinasi terdapat 10 ulangan, sehingga percobaan tersebut dibutuhkan 80 unit pot organik dan semai suren.

Tabel 1 Hasil analisis kimia pot organik semai suren

\begin{tabular}{lccccc}
\hline \multicolumn{1}{c}{ Jenis perlakuan } & Ptotal (ppm) & $\begin{array}{c}\text { Ptersedia } \\
(\mathrm{ppm})\end{array}$ & $\mathrm{N}(\%)$ & $\begin{array}{c}\text { C organik } \\
(\%)\end{array}$ & C/N rasio (\%) \\
\hline Koran 100\% (P1) & 148.84 & 5.04 & 0.24 & 13.24 & 55.16 \\
Koran + cocopeat 1:3 (P2) & 161.78 & 9.66 & 0.30 & 16.92 & 56.4 \\
Koran + arang sekam 2:3 (P3) & 483.32 & 40.64 & 0.57 & 7.54 & 13.22 \\
Koran + cocopeat + arang & 541.96 & 19.40 & 0.44 & 6.33 & 14.38 \\
sekam 1:1:1 (P4) & & & & & \\
\hline
\end{tabular}




\section{HASIL DAN PEMBAHASAN}

\section{Kandungan Hara Pot Organik}

Kandungan unsur hara pada pot organik yang dianalisis terdiri atas kandungan unsur $\mathrm{N}$ (nitrogen), $\mathrm{P}$ (fosfor), $\mathrm{C}$ (karbon) dan $\mathrm{C} / \mathrm{N}$ rasio yang hasilnya dapat dilihat pada Tabel 1.

Berdasarkan hasil analisis kimia pada pot organik, kandungan unsur hara $\mathrm{P}$ total tertinggi terdapat pada perlakuan P4 (koran:cocopeat:arang sekam 1:1:1) yaitu $541.96 \mathrm{ppm}$ dan $\mathrm{P}$ tersedia tertinggi terdapat pada perlakuan P3 (koran:arang sekam 2:3) yaitu 40.64 ppm. Begitu juga pada unsur N perlakuan P3 (Koran:arang sekam 2:3) memiliki kandungan unsur hara tertinggi yaitu $0.57 \%$. Hal ini karena pada kedua perlakuan tersebut menggunakan bahan organik berupa arang sekam, menurut Soemeinaboedhy dan Tejowulan (2007) bahan organik yang berupa arang sekam memiliki kemampuan untuk meningkatkan unsur $\mathrm{P}$ yang ada pada tanah, selain itu juga arang sekam mempunyai potensi sebagai penyerap dan pelepas unsur hara (pupuk) dalam bidang kesuburan tanah. Sehingga pemberian arang sekam dalam dosis yang cukup dapat memberikan hasil yang baik. Irawan dan Yeremias (2015) menyatakan bahwa selain unsur $\mathrm{P}$, penambahan arang sekam juga dapat meningkatkan kandungan unsur N, karena arang sekam memiliki pori - pori yang lebih besar sehingga mampu menyerap unsur hara yang ada disekitarnya untuk disimpan didalam pori-pori tersebut, sehingga pertumbuhan tanaman menjadi lebih baik.

Kandungan unsur $\mathrm{C}$ organik tertinggi terdapat pada perlakuan P2 (Koran:cocopeat 1:3) dan P1 (koran 100\%) yaitu sebesar $16.92 \%$ dan $13.24 \%$. Sedangkan pada perlakuan P3 (Koran:arang sekam 2:3) dan P4 (Koran:cocopeat:arang sekam 1:1:1) memiliki nilai C organik sebesar $7.54 \%$ dan $6.33 \%$. Peningkatan dan penurunan nilai unsur hara $\mathrm{C}$ organik diakibatkan oleh adanya proses dekomposisi, serta semakin berkurangnya kandungan unsur $\mathrm{C}$ organik maka banyaknya $\mathrm{C}$ organik tersebut yang terserap oleh tanaman, selain itu adanya persaingan pemanfaatan $\mathrm{C}$ organik oleh mikroorganisme lainnya yang terdapat didalam media tanam (Akhir 2005).

Tabel 2 Hasil analisis sidik ragam pengaruh interaksi komposisi pot organik dan penambahan FMA terhadap pertumbuhan semai suren

\begin{tabular}{lc}
\hline \multicolumn{1}{c}{ Parameter } & Analisis sidik ragam \\
\hline Tinggi & $0.0472^{*}$ \\
Diameter & $0.0001^{*}$ \\
Berat kering total & $0.9259 \mathrm{tn}$ \\
Kolonisasi FMA & $0.4474 \mathrm{tn}$ \\
\hline
\end{tabular}

\section{Keterangan:}

Angka-angka dalam tabel adalah nilai signifikan.

$*=$ perlakuan berpengaruh nyata pada selang kepercayaan $95 \%$ dengan nilai signifikan $(\mathrm{Pr}>\mathrm{F}) 0.05$ $(\alpha)$

tn = perlakuan tidak berpengaruh nyata pada selang kepercayaan $95 \%$ dengan nilai signifikan $(\operatorname{Pr}>\mathrm{F}) 0.05$ $(\alpha)$
Salah satu aspek penting dari keseimbangan hara total adalah rasio organik karbon dengan nitrogen $(\mathrm{C} / \mathrm{N})$. Berdasarkan kriteria penilaian unsur hara tanah menurut Hardjowigeno (1987) rasio $\mathrm{C} / \mathrm{N}<5=$ sangat rendah, 5-10 $=$ rendah, $11-15=$ sedang, $16-25=$ tinggi dan $>25$ =sangat tinggi. Perlakuan P3 (Koran:arang sekam 2:3) dan P4 (Koran:cocopeat:arang sekam 1:1:1) memiliki rasio $\mathrm{C} / \mathrm{N}$ sedang karena berada pada selang $11-15$ yaitu sebesar $13.22 \%$ dan $14.38 \%$. Hal ini menunjukkan bahwa aktivitas mikroorganisme tinggi dalam menguraikan atau mendekomposisi bahan organik sehingga ketersediaan unsur hara tinggi dan tanaman dapat memenuhi kebutuhan hidupnya (Widarti et al. 2015).

\section{Pengaruh Interaksi Komposisi Pot Organik dan Penambahan FMA}

Hasil analisis sidik ragam pengaruh komposisi pot organik dan penambahan FMA dapat dilihat pada Tabel 2. Berdasarkan hasil analisis sidik ragam (Tabel 2) parameter tinggi dan parameter diameter memiliki pengaruh yang nyata terhadap interaksi komposisi pot organik dan penambahan FMA. Uji duncan interaksi komposisi pot organik dan penambahan FMA terhadap tinggi semai suren dapat dilihat pada Tabel 3. Uji duncan interaksi komposisi pot organik dan penambahan FMA terhadap diameter semai suren dapat dilihat pada Tabel 4.

Berdasarkan hasil pengamatan diatas didapatkan bahwa perlakuan P3M (koran: arang sekam 2:3 FMA) pada parameter tinggi (Tabel 3) dan diameter (Tabel 4) memiliki respon pertumbuhan yang paling baik dibandingkan dengan perlakuan lainnya. Hal ini apabila dikaitkan dengan kandungan unsur hara (Tabel 1) perlakuan yang menggunakan koran : arang sekam 2:3 rmemiliki kandungan unsur hara $\mathrm{N}, \mathrm{P}$ tersedia, $\mathrm{P}$ total , C dan $\mathrm{C} / \mathrm{N}$ yang paling baik dibandingkan dengan perlakuan yang lainnya. Unsur-unsur tersebut diperlukan tanaman untuk memenuhi nutrisinya dalam proses

Tabel 3 Uji duncan interaksi komposisi pot organik dan penambahan FMA terhadap pertumbuhan tinggi suren

\begin{tabular}{lcc}
\hline Perlakuan & $\begin{array}{c}\text { Rata-rata } \\
(\mathrm{cm})\end{array}$ & $\begin{array}{c}\% \\
\text { peningkatan }\end{array}$ \\
\hline $\begin{array}{l}\text { Koran 100\% tanpa FMA } \\
\text { (P1) }\end{array}$ & $2.82^{d}$ & 0 \\
$\begin{array}{l}\text { Koran 100\% FMA(P1M) } \\
\text { Koran:cocopeat 1:3 tanpa }\end{array}$ & $4.65^{d}$ & 64.89 \\
$\begin{array}{l}\text { FMA(P2) } \\
\text { Koran:cocopeat 1:3 FMA }\end{array}$ & $10.78^{c}$ & 211.34 \\
$\begin{array}{l}\text { (P2M) } \\
\text { Koran:arang sekam 2:3 }\end{array}$ & $14.57^{b}$ & 274.82 \\
tanpa FMA (P3) & 414.53 \\
$\begin{array}{l}\text { Koran:arang sekam 2:3 } \\
\text { FMA(P3M) }\end{array}$ & $20.30^{a}$ & 619.85 \\
$\begin{array}{l}\text { Koran:cocopeat:arang } \\
\text { sekam 1:1:1 tanpa FMA }\end{array}$ & $15.18^{b}$ & 438.29 \\
$\begin{array}{l}\text { (P4) } \\
\text { Koran:cocopeat:arang } \\
\text { sekam 1:1:1 FMA }\end{array}$ & $14.44^{b}$ & 412.05 \\
(P4M) & & \\
\hline
\end{tabular}

Keterangan: Angka yang diikuti oleh huruf yang sama menunjukkan perlakuan tidak berbeda nyata pada selang kepercayaan $95 \%$. 
pertumbuhan. Menurut Kusmarwiyah dan Erni (2011) bahan organik yang berupa arang sekam memiliki keunggulan seperti memperbaiki porositas media sehingga baik untuk respirasi akar, penyerapan senyawa fenol, dan mempertahankan kelembaban tanah. Sifat arang sekam tersebut yang dapat menyebabkan pertumbuhan tinggi dan pertumbuhan diameter tanaman menjadi lebih baik. Selain itu dengan penambahan FMA dapat membantu penyerapan unsur hara tanaman terutama unsur $\mathrm{P}$ sehingga pertumbuhan tanaman menjadi lebih baik dan dapat meningkatkan ketahanan terhadap kondisi kering, penyakit, serta kondisi tidak menguntungkan lainnya. (Wicaksono et al. 2014).

Perlakuan P4 (Koran:cocopeat:arang sekam 1:1:1 tanpa FMA) dan perlakuan P4M (Koran:cocopeat:arang sekam 1:1:1 FMA) memiliki pertumbuhan tinggi dan diameter yang baik dibandingkan dengan perlakuan P2M (Koran:cocopeat 1:3 FMA) dan P2 (Koran:cocopeat 1:3 tanpa FMA). Hal ini salah satunya karena pada perlakuan P4 (Koran: cocopeat:arang sekam 1:1:1 tanpa FMA) dan perlakuan P4M (Koran:cocopeat:arang sekam 1:1:1 FMA) terdapat campuran bahan organik lain seperti arang sekam yang memiliki fungsi yang baik. Pada perlakuan P2M (Koran:cocopeat 1:3 FMA) dan P2 (Koran:cocopeat 1:3 tanpa FMA) hanya menggunakan bahan organik cocopeat saja. Media cocopeat memiliki pori mikro yang dapat menghambat gerakan air yang lebih besar sehingga dapat menyebabkan ketersediaan air tinggi dan menyebabkan pertukaran gas pada media mengalami hambatan karena media mulai jenuh dengan air (Istomo dan Valentino 2012). Selain itu apabila dikaitkan dengan kandungan unsur hara perlakuan koran:cocopeat 1:3 memiliki kandungan unsur hara $\mathrm{N}, \mathrm{P}$ tersedia, $\mathrm{P}$ total, $\mathrm{C}$ dan $\mathrm{C} / \mathrm{N}$ yang rendah dibandingkan dengan koran : arang sekam 2:3 (Tabel 1), sehingga unsur- unsur hara yang dibutuhkan oleh tanaman juga sedikit.

Perlakuan P1M (Koran 100\% FMA) dan P1 (Koran $100 \%$ tanpa FMA) memiliki rata-rata pertumbuhan tinggi dan diameter yang rendah dibandingkan dengan

Tabel 4 Uji duncan interaksi komposisi pot organik dan penambahan FMA terhadap pertumbuhan diameter suren

\begin{tabular}{|c|c|c|}
\hline Perlakuan & $\begin{array}{c}\text { Rata-rata } \\
(\mathrm{mm})\end{array}$ & $\begin{array}{c}\% \\
\text { peningkatan }\end{array}$ \\
\hline $\begin{array}{l}\text { Koran } 100 \% \text { tanpa FMA } \\
\text { (P1) }\end{array}$ & $0.71^{e}$ & 0 \\
\hline Koran $100 \%$ FMA(P1M) & $0.75^{e}$ & 5.63 \\
\hline $\begin{array}{l}\text { Koran:cocopeat } 1: 3 \text { tanpa } \\
\text { FMA(P2) }\end{array}$ & $1.02^{d}$ & 43.66 \\
\hline $\begin{array}{l}\text { Koran:cocopeat 1:3 FMA } \\
\text { (P2M) }\end{array}$ & $1.19^{c}$ & 67.605 \\
\hline $\begin{array}{l}\text { Koran:arang sekam 2:3 } \\
\text { tanpa FMA (P3) }\end{array}$ & $1.40^{b}$ & 97.18 \\
\hline $\begin{array}{l}\text { Koran:arang sekam 2:3 } \\
\text { FMA(P3M) }\end{array}$ & $1.79^{a}$ & 152.11 \\
\hline $\begin{array}{l}\text { Koran:cocopeat:arang } \\
\text { sekam 1:1:1 tanpa FMA } \\
\text { (P4) }\end{array}$ & $1.49^{b}$ & 109.85 \\
\hline $\begin{array}{l}\text { Koran:cocopeat:arang } \\
\text { sekam 1:1:1 FMA (P4M) }\end{array}$ & $1.36^{b}$ & 91.54 \\
\hline
\end{tabular}

Keterangan: Angka yang diikuti oleh huruf yang sama menunjukkan perlakuan tidak berbeda nyata pada selang kepercayaan $95 \%$. perlakuan yang lain. Hal ini karena pada perlakuan tersebut memiliki kandungan unsur hara $\mathrm{N}, \mathrm{P}$ tersedia, $\mathrm{P}$ total, $\mathrm{C}$ dan $\mathrm{C} / \mathrm{N}$ (Tabel 1) yang paling rendah karena pada perlakuan tersebut hanya menggunakan media kertas koran saja tanpa tambahan bahan organik yang lain.

Pertumbuhan tinggi dan diameter pada tanaman salah satunya dibantu dengan penambahan FMA. Menurut Haris dan Adnan (2000) manfaat penambahan FMA menjadikan pertumbuhan tanaman menjadi lebih baik. Hal ini karena FMA mampu meningkatkan luasan penyerapan hara. Akar tanaman yang bermikorhiza memiliki bidang penyerapan unsur hara yang lebih luas yaitu lebih dari $1.800 \%$ (Orcutt dan Nielsen 2000). Tetapi pertumbuhan tinggi dan pertumbuhan diameter tanaman yang diberi penambahan FMA memiliki pertumbuhan yang berbeda-beda, hal ini salah satunya diakibatkan oleh jumlah FMA yang ada didalam tanah dipengaruhi oleh beberapa faktor seperti FMA itu sendiri, tanaman inangnya, serta kondisi lingkungan seperti pengaruh cahaya dan suhu (Patriyasari 2006).

\section{Pengaruh Komposisi Pot Organik}

Hasil analisis sidik ragam pengaruh komposisi pot organik terhadap semai suren dapat dilihat pada Tabel 5 . Berdasarkan hasil analisis sidik ragam pengaruh tunggal komposisi pot organik berpengaruh nyata terhadap berat kering total (BKT).

Hasil uji duncan pengaruh tunggal komposisi pot organik terhadap BKT dapat dilihat pada Tabel 6 . Berdasarkan hasil pada Tabel 6 perlakuan P3 (Koran:arang sekam 2:3) lebih unggul dibandingkan dengan perlakuan yang lainnya dengan rata-rata 13.974 gram dan peningkatan sebesar $19.589 \%$ dibandingkan kontrolnya, hal ini karena unsur hara $\mathrm{N}, \mathrm{P}$ tersedia, $\mathrm{P}$ total, $\mathrm{C}$ dan $\mathrm{C} / \mathrm{N}$ (Tabel 1) pada perlakuan tersebut memiliki kandungan unsur hara yang paling baik dan bahan organik arang sekam memiliki sifat yang lebih remah yang dapat mempercepat proses perkembangan akar, dimana pertumbuhan akar berfungsi untuk mendapatkan hara dan air untuk memenuhi nutrisi tanaman. Menurut pernyataan Sukaryorini dan Arifin (2007) arang sekam mampu memberikan respon yang lebih baik terhadap berat basah tanaman dan berat kering tanaman. Semakin besar berat kering total tanaman maka kualitas semai akan semakin baik, karena menandakan kemampuan semai tersebut dalam menyerap hara mineral dari media yang akan diubah menjadi organ

Tabel 5 Hasil analisis sidik ragam pengaruh komposisi pot organik terhadap berat kering total dan kolonisasi FMA.

\begin{tabular}{lc}
\hline \multicolumn{1}{c}{ Parameter } & analisis sidik ragam \\
\hline Berat kering total (BKT) & $0.0014^{*}$ \\
Kolonisasi FMA & $0.1126 \mathrm{tn}$ \\
\hline
\end{tabular}

Keterangan:

Angka-angka dalam tabel adalah nilai signifikan.

$*=$ perlakuan berpengaruh nyata pada selang kepercayaan 95\% dengan nilai signifikan $(\mathrm{Pr}>\mathrm{F}) 0.05$ $(\alpha)$

tn $=$ perlakuan tidak berpengaruh nyata pada selang kepercayaan 95\% dengan nilai signifikan $(\operatorname{Pr}>\mathrm{F}) 0.05$ $(\alpha)$ 
tanaman yang baru (Indriani 2002). Hasil dari berat kering merupakan keseimbangan antara proses fotosintesis dan respirasi. Fotosintesis mengakibatkan peningkatan berat kering tanaman karena adanya proses pengambilan $\mathrm{CO}_{2}$, sedangkan respirasi mengakibatkan penurunan berat kering karena pengeluaran $\mathrm{CO}_{2}$.

\section{Pengaruh Penambahan FMA}

Hasil analisis sidik ragam pengaruh penambahan FMA terhadap pertumbuhan semai suren dapat dilihat pada Tabel 7. Berdasarkan hasil analisis sidik ragam tersebut penambahan FMA berpengaruh nyata terhadap kolonisasi FMA. Hasil uji duncan pengaruh penambahan FMA terhadap kolonisasi FMA dapat dilihat pada Tabel 8. Berdasarkan hasil dari uji duncan penambahan FMA terhadap kolonisasi FMA didapatkan hasil bahwa perlakuan dengan menggunakan FMA lebih baik dengan nilai rata-rata kolonisasi sebesar $28.500 \%$, dibandingkan dengan perlakuan tanpa FMA yaitu $8.000 \%$ dan persentase peningkatan sebesar $256.25 \%$ dibandingkan dengan perlakuan tanpa menggunakan FMA. Simbiosis antara FMA dengan tanaman dapat diketahui dengan adanya tingkat infeksi FMA pada akar tanaman. Infeksi FMA ini berupa arbuskula, vasikula, spora dan hifa. Besar rendahnya tingkat infeksi FMA dipengaruhi oleh banyak faktor, seperti faktor kandungan air tanah, ph

Tabel 6 Uji duncan pengaruh komposisi pot organik terhadap berat kering total semai suren

\begin{tabular}{lcc}
\hline Perlakuan & $\begin{array}{c}\text { Rata }- \text { rata } \\
\text { (gram) }\end{array}$ & $\begin{array}{c}\text { Peningkatan } \\
\text { terhadap } \\
\text { perlakuan koran } \\
(\%)\end{array}$ \\
\hline $\begin{array}{l}\text { Koran+ arang } \\
\text { sekam 2:3 (P3) }\end{array}$ & $13.974^{a}$ & 19.589 \\
$\begin{array}{l}\text { Koran+cocopeat }+ \\
\text { arang sekam }\end{array}$ & $12.897^{a b}$ & 10.372 \\
$\begin{array}{l}1: 1: 1(\mathrm{P} 4) \\
\text { Koran+cocopeat }\end{array}$ & $12.210^{b c}$ & 4.493 \\
$\begin{array}{l}\text { 1:3 (P2) } \\
\text { Bubur kertas koran }\end{array}$ & $11.685^{c}$ & 0 \\
$100 \%$ (P1) & & 0 \\
\hline
\end{tabular}

Keterangan: Angka yang diikuti oleh huruf yang sama menunjukkan perlakuan tidak berbeda nyata pada selang kepercayaan $95 \%$.

Tabel 7 Hasil analisis sidik ragam pengaruh penambahan FMA terhadap parameter berat kering total (BKT) dan kolonisasi FMA semai suren.

\begin{tabular}{lc}
\hline \multicolumn{1}{c}{ Parameter } & analisis sidik ragam \\
\hline Berat kering total (BKT) & 0.1020 tn \\
Kolonisasi FMA & $<.0001^{*}$ \\
\hline
\end{tabular}

Keterangan: Angka-angka dalam tabel adalah nilai signifikan

* = perlakuan berpengaruh nyata pada selang kepercayaan 95\% dengan nilai signifikan $(\operatorname{Pr}>\mathrm{F}) 0.05$ $(\alpha)$.

tn $=$ perlakuan tidak berpengaruh nyata pada selang kepercayaan 95\% dengan nilai signifikan $(\operatorname{Pr}>\mathrm{F}) 0.05$ $(\alpha)$ tanah, bahan organik, dan lingkungan (cahaya dan suhu). Cahaya matahari berperan dalam pembentukan karbohidrat melalui asimilasi karbon, setelah itu FMA akan menggunakan karbon tersebut sebagai sumber energi untuk pertumbuhannya (Wicaksono et al. 2014).

Pengamatan FMA yang dilakukan merupakan jenis endomikorhiza. Setelah dilakukan pengamatan dengan mikroskop perlakuan yang tanpa FMA juga terdapat infeksi meskipun rata-rata kolonisasinya hanya sedikit (Tabel 8). Hal ini karena endomikorhiza hampir dapat ditemukan pada semua tanah dan tidak memiliki inang yang spesifik. Menurut Tamin et al. (2012) setiap ekosistem mempunyai kemungkinan dapat mengandung endomikorhiza dengan jenis yang sama atau berbeda, hal ini disebabkan oleh keanekaragaman dan penyebaran endomikorhiza sangat bervariasi akibat kondisi lingkungan yang bervariasi juga.

\section{Nisbah Pucuk Akar}

Nisbah puck akar (NPA) merupakan perbandingan antara berat kering pucuk dengan berat kering akar. Hasil pengukuran nisbah pucuk akar (NPA) pada semai suren dapat dilihat pada Gambar 1. Berdasarkan hasil rata-rata nilai nisbah pucuk akar pada Gambar 1, perlakuan dengan menggunakan FMA memiliki nilai NPA lebih tinggi dibandingkan dengan perlakuan yang tanpa FMA. Pada perlakuan dengan FMA rata-rata nilai NPA tertinggi terdapat pada perlakuan P3M (Koran:arang sekam 2:3 FMA) sebesar $1.78 \%$, dan perlakuan tanpa FMA rata-rata nilai NPA yang tertinggi terdapat pada perlakuan P3 (koran+arang sekam tanpa FMA) yaitu sebesar $1.72 \%$.

Menurut Duryea dan Brown (1984) nilai nisbah pucuk akar yang baik berkisar antara 1-3. Pada Gambar 5 rata-rata nilai NPA pada masing-masing perlakuan yaitu $>1$, sehingga dapat dinyatakan baik. NPA yang tinggi dengan produksi biomassa total yang besar pada tanah yang subur secara tidak langsung menunjukan bahwa akar relatif sedikit, dan cukup untuk mendukung pertumbuhan tanaman yang relatif besar dalam menyediakan air dan unsur hara (Sitompul dan Guritno 1995). Perlakuan P3 (Koran:arang sekam 2:3 tanpa FMA) dan perlakuan P3M (Koran : arang sekam 2:3 FMA) memiliki kondisi yang sama dengan pernyataan tersebut, sehingga pemberian bahan organik dan penambahn FMA dapat meningkatkan NPA tanaman suren. Hal ini juga didukung dengan kandungan unsur hara (Tabel 1) N, P tersedia, $\mathrm{P}$ total, $\mathrm{C}$ dan $\mathrm{C} / \mathrm{N}$ pada perlakuan yang menggunakan koran : arang sekam 2:3

Tabel 8 Uji duncan pengaruh penambahan FMA terhadap kolonisasi FMA.

\begin{tabular}{lcc} 
Perlakuan & $\begin{array}{c}\text { Rata-rata } \\
\text { kolonisasi } \\
\text { FMA (\%) }\end{array}$ & $\begin{array}{c}\% \\
\text { peningkatan }\end{array}$ \\
\hline Tanpa FMA & $8.000^{b}$ & 0 \\
Dengan FMA & $28.500^{a}$ & 256.25 \\
\hline
\end{tabular}

Keterangan: Angka yang diikuti oleh huruf yang sama menunjukkan perlakuan tidak berbeda nyata pada selang kepercayaan $95 \%$. 
memiliki unsur hara yang tinggi sehingga mampu untuk mendukung pertumbuhan tanaman. NPA yang rendah terdapat pada tanaman yang kekurangan air dan unsur hara yang akan berusaha membentuk akar yang lebih banyak untuk meningkatkan serapan air dan unsur hara tersebut (Sitompul dan Guritno 1995). Pada umumnya sistem perakaran dipengaruhi oleh faktor genetik dari pada faktor lingkungan, tetapi bagaimanapun juga lingkungan ikut berperan, seperti ketika kondisi tanah kering banyak spesies yang menumpuk sehingga biomassanya lebih besar di akar.

\section{SIMPULAN DAN SARAN}

\section{Simpulan}

Perlakuan P3M (koran:arang sekam 2:3 FMA) yang berpengaruh nyata terhadap komposisi pot dan penambahan FMA, memiliki hasil terbaik terhadap parameter tinggi dan diameter. Begitu juga perlakuan koran: arang sekam 2:3 berpengaruh nyata terhadap pemberian tunggal komposisi pot organik memberikan hasil terbaik pada terhadap parameter berat kering total (BKT). Penambahan tunggal FMA berpengaruh nyata terhadap parameter kolonisasi FMA memberikan hasil yang terbaik terhadap perlakuan dengan FMA dibandingkan tanpa FMA. Hasil yang terbaik pada nisbah pucuk akar (NPA) terdapat pada perlakuan P3M (koran:arang sekam 2:3 FMA) dan P3 (koran:arang sekam 2:3 tanpa FMA). Perlakuan yang menggunakan bahan organik koran:arang sekam menghasilkan respon pertumbuhan tanaman yang terbaik, karena pada perlakuan tersebut memiliki kandungan unsur hara $\mathrm{N}, \mathrm{P}$ tersedia, $\mathrm{P}$ total , $\mathrm{C}$ dan $\mathrm{C} / \mathrm{N}$ yang paling baik sehingga unsur hara untuk pertumbuhan tanaman tercukupi.

\section{SARAN}

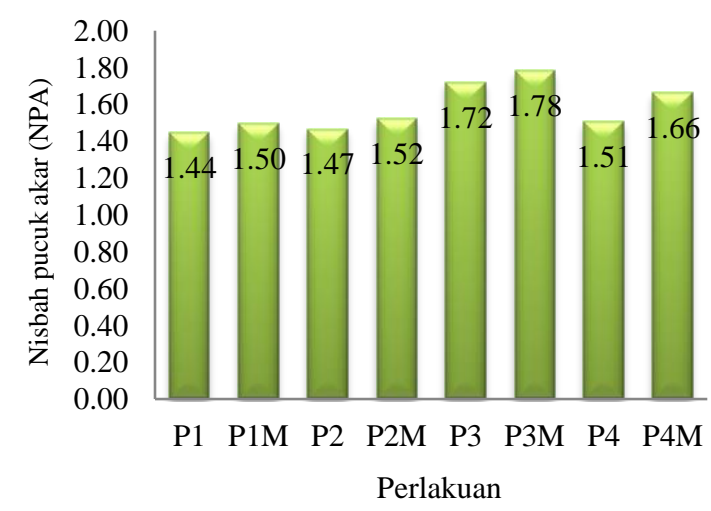

Gambar 1 Rata-rata NPA pada perlakuan P1(koran $100 \%$ tanpa FMA), P1M (koran 100\% FMA), P2 (koran+cocopeat tanpa FMA), P2M (koran+cocopeat FMA), P3 (koran+arang sekam tanpa FMA), P3M (koran+arang sekam FMA), P4 (koran+cocopeat+arang sekam tanpa FMA), P4M (koran+cocopeat+arang sekam FMA).
Perlu adanya pengujian penggunaan pot organik dilapangan dan penggunaan komposisi pot organik yang berbeda untuk mengetahui pengaruh terhadap pertumbuhan tanaman

\section{DAFTAR PUSTAKA}

Akhir J. 2005. Pembuatan dan pengujian wadah semai ramah lingkungan di rumah kaca dan lapangan. [tesis]. Bogor (ID): Institut Pertanian Bogor.

Astana S. 2012. Dampak kebijakan makroekonomi dan faktor eksternal terhadap deforestasi dan degradasi hutan alam [disertasi]. Bogor (ID): Institut Pertanian Bogor.

Budi SW, Sukendro A, Karlinasari L. 2012. Penggunaan pot berbahan dasar organik untuk pembibitanan Gmelina arborea roxb. di Persemaian. J Agron. Indonesia. 40(3):239-245.

Duryea ML, Brown GN. 1984. Seedling physiology and reforestation success. Proceeding of the Physiology Working Technical Session. Boston (US): Dr. W Junk Publisher.

Hardjowigeno S. 1987. Ilmu Tanah. Jakarta (ID): PT. Melton Putra.

Haris A, Adnan AM. 2000. Mikoriza dan manfaatnya. Prosiding Seminar Ilmiah dan Pertemuan Tahunan PEI dan PFI XVI Komda Sul-Sel. Sulawesi Selatan (ID): Balai Penelitian Tanaman Serelia.

Hasyah SS. 2015. Penggunaan pot organik praktis untuk pembibitan Suren (Toona sinensis Roem.) di rumah kaca [skripsi]. Bogor (ID): Institut Pertanian Bogor.

Indriani H. 2002. Pertumbuhan semai A. mangium Willd. pada berbagai media kompos dengan ekstrak kedelai (Glycine max Merr.). [skripsi]. Bogor (ID): Institut Pertanian Bogor.

Irawan A, Yeremias K. 2015. Pemanfaatan cocopeat dan arang sekam padi sebagai media tanam bibit cempaka wasian (Elmerrilia ovalis). Pros Sem Nas Masy Biodiv Indon. Vol.1 (4): 805-808.

Istomo, Valentino N. 2012. Pengaruh perlakuan kombinasi media terhadap pertumbuhan anakan tumih (Combretocarpus rotundatus Miq. Danser). Jurnal Silvikultur Tropika. Vol. 3 (2): 81-84.

Kartika E. 2006. Tanggap pertumbuhan, serapan hara dan karakter morfofisiologi terhadap cekaman kekeringan pada bibit kelapa sawit yang bersimbiosis dengan CMA [disertasi]. Bogor (ID): Program Pasca Sarjana IPB.

Kementerian Kehutanan. 2011. Statisitik Kehutanan 2011 . Jakarta (ID) : Kementrian Kehutanan RI.

Kusmarwiyah R, Erni S. 2011. Pengaruh media tumbuh dan pupuk organik cair terhadap pertumbuhan dan hasil tanaman seledri (Apium graveolens L.). Crop Agro. Vol. 4 (2): 7-12.

Orcutt DM, Nielsen ET. 2000. Physiology of Plants Under Stress: Biotic Factor. Canada (US): John wiley \& Sons Inc.

Patriyasari T. 2006. Efektivitas cendawan mikoriza arbuskula terhadap pertumbuhan dan 
produktivitas Cynodon dactylon yang diberi level salinitas berbeda. [skripsi]. Bogor (ID): Fakultas Peternakan Institut Pertanian Bogor.

Rohmah B. 2015. Penggunaan pot organik untuk pembibitan Mindi (Melia Azedarach L.)di rumah kaca [skripsi]. Bogor (ID): Institut Pertanian Bogor.

Sitompul SM, Guritno B. 1995. Analisa Pertumbuhan Tanaman. Yogyakarta (ID): Gadjah Mada University Press.

Sjarief R. 2010. Tata Ruang Air. Yogyakarta (ID): Penerbit Andi.

Soemeinaboedhy NI, Tejowulan SR. 2007. Pemanfaatan berbagai macam arang sebagi sumber unsur hara $\mathrm{P}$ dan $\mathrm{K}$ serta sebagai pembenah tanah. Agroteksos. Vol. 17 (2).

Sukaryorini P, Arifin. 2007. Kajian pembentukan caudex Adenium obesum pada diversifikasi media tanam. Jurnal Pertanian Mapeta. Vol. 10 (1): 31-41.
Syaputra T. 2011. Pembuatan dan pengujian wadah semai berbahan dasar organik untuk pembiitan Gmelina (Gmelina arborea Roxb.) di Persemaian [skripsi]. Bogor (ID): Institut Pertanian Bogor.

Tamin RP, Nursanti, Albayudi. 2012. Identifikasi jenis dan perbanyakan endomikoriza lokal di hutan kampus universitas jambi. Jurnal Penelitian Universitas Jambi Seri SAINS. Vol.14 (1): 23-28.

Wicaksono IM et al. 2014. Pengaruh pemberian mikoriza dan pupuk organik terhadap pertumbuhan bawang putih. Jurnal Ilmu Ilmu Pertanian. Vol. XXIX No. 1.

Widarti NB, Wardhini KS, Sarwono E. 2015. Pengaruh rasio $\mathrm{C} / \mathrm{N}$ bahan baku pada pembuatan kompos dari kubis dan kulit pisang. Jurnal Integrasi Proses . Vol.5 (2) : 75-80. 